\title{
PERLINDUNGAN HUKUM DALAM PERGADANGAN BERJANGKA KOMODITI BERDASARKAN PRINSIP SYARIAH
}

\author{
Citra Julian Lestari \\ Program Studi Magister Ilmu Hukum, Pascasarjana Universitas Islam Bandung \\ Email : cjlestari29@gmail.com
}

\begin{abstract}
Abstrak - Perdagangan berjangka komoditi merupakan suatu bentuk investasi atau lahan mencari uang yang dilakukan masyarakat di era globalisasi dikarenakan memiliki potensi keuntungan lebih besar dibanding investasi lainnya. Dari segi bentuk perdagangannya, dalam perdagangan berjangka komoditi yang diperdagangkan adalah janji atau kesepakatan untuk menyerahkan atau menerima suatu barang tertentu dikemudian hari. Penulisan ini bertujuan untuk mengetahui perlindungan hukum dalam transaksi perdagangan berjangka komoditi ditinjau dari Fatwa DSN MUI Nomor 82 Tahun 2011 tentang Perdagangan Komoditi Berdasarkan Prinsip Syariah di Bursa Komoditi. Metode penelitian yang digunakan adalah yuridis normatif yang bersifat deskriptif, dengan menggunakan data sekunder melalui studi kepustkaan yang dianalisis secara kualitatif. Hasil penelitian menunjukan bahwa perdagangan berjangka komoditi yang diatur dalam fatwa bertujuan sebagai sarana lindung nilai rupiah di pasar dan dilarang mengandung unsur gharar, riba, dan batil.
\end{abstract}

Kata Kunci : Perlindungan Hukum, Perdagangan Berjangka Komoditi

\begin{abstract}
Commodity futures trading is a form of investment or land seeking money made by people in the era of globalization because of the potential for greater profits than other investments. In terms of the form of trade, in futures trading traded commodities are promises or agreements to deliver or receive certain items in the future. This writing aims to determine the legal protection in commodity futures trading transactions in terms of the MUI DSN Fatwa Number 82 of 2011 concerning Commodity Trading Based on Sharia Principles on the Commodity Exchange. The research method used is normative juridical which is descriptive in nature, using secondary data through a literature study that is analyzed qualitatively. The research results show that commodity futures trading regulated in the fatwa are intended as a means of hedging the rupiah in the market and is prohibited from containing elements of gharar, usury and vanity.
\end{abstract}

Keyword : Legal Protection, Commodity Futures Trading

\section{A. PENDAHULUAN}

Pada era globalisasi, transaksi perdagangan berjangka komoditi dijadikan sebagai suatu bentuk investasi atau lahan mencari uang karena investasi pada perdagangan komoditi pada dasarnya mempunyai potensi keuntungan lebih besar dibandingkan tabungan atau deposito, bahkan bisa melebihi saham atau obligasi. Namun demikian, investasi pada 
perdagangan berjangka komoditi juga harus dilakukan dengan berhati-hati karena memiliki risiko lebih besar serta tidak dijamin oleh pemerintah. Sehingga sangatlah penting adanya kepastian hukum untuk memberikan perlindungan hukum bagi investor dalam transaksi perdagangan berjangka komoditi.

Perlindungan hukum dalam transaksi perdagangan berjangka komoditi yaitu suatu sarana lindung nilai dan pengelolaan resiko dalam transaksi perdagangan berjangka komoditi. Perdagangan berjangka komoditi memiliki hubungan timbal balik dan sebanding dalam transaksi, yaitu high risk high return yang artinya kemungkinan investor untuk mendapatkan keuntungan dari transaksi atau kontrak berjangka sama besarnya dengan kemungkinan kerugian (Allysthia M. Renti D, 2012:53). Investor dapat menderita kehilangan seluruh dana yang telah disetorkan. Dengan demikian, calon investor yang mengikuti transaksi perdagangan berjangka komoditi ini merupakan seorang investor yang berani dalam menghadapi resiko kerugian dan kuat mental (Andam Dewi, Hermanto Siregar, Sri Hartoyo, 2011 : 23).

Pasal 1 Angka 1 Undang-Undang Nomor 10 Tahun 2011 Tentang Perdagangan Berjangka Komoditi mendefinisikan perdagangan berjangka komoditi adalah segala sesuatu yang berkaitan dengan jual beli komoditi yang dilakukan dengan penarikan sejumlah margin dari investor dengan penyerahan transaksinya kemudian dilakukan berdasarkan kontrak berjangka, kontrak derivatif syariah, dan kontrak derivatif lainnya. Dari segi bentuk perdagangannya, dalam perdagangan berjangka komoditi yang diperdagangkan adalah janji atau kesepakatan untuk menyerahkan atau menerima suatu barang tertentu dikemudian hari.

Pelaksanaan investasi pada perdagangan berjangka komoditi adalah dengan jalan membeli kontrak-kontrak berjangka komoditi melalui pialang/wakil pialang berjangka. Hal ini karena untuk melakukan investasi di bursa berjangka tidak dapat dilakukan secara langsung oleh masyarakat umum, yaitu untuk melakukan transaksi secara langsung di bursa berjangka akan tetapi harus melalui pialang/wakil pialang berjangka melalui perjanjian kerja sama investasi diantara para pihak. Sehingga dengan sendirinya, pialanglah yang akan mengeksekusi semua bentuk transaksi dari nasabah yang dimasukkan ke dalam bursa berjangka (Galih Mahendratama Putra, Budiharto, Siti Mahmudah, 2012 : 3-5). 
Di Indonesia, perdagangan berjangka komoditi bagi umat muslim diatur dalam Fatwa DSN MUI Nomor 82 Tahun 2011 tentang Perdagangan Komoditi Berdasarkan Prinsip Syariah di Bursa Komoditi yang merupakan suatu bentuk perlindungan hukum dalam rangka memberikan kepastian hukum bagi investor (muslim) dalam melakukan transaksi perdagangan berjangka komoditi agar sesuai dengan prinsip-prinsip hukum islam.

\section{Identifikasi Masalah}

Bagaimana perlindungan hukum bagi investor dalam transaksi perdagangan berjangka komoditi ditinjau dari Fatwa DSN MUI Nomor 82 Tahun 2011 tentang Perdagangan Komoditi Berdasarkan Prinsip Syariah di Bursa Komoditi.

\section{Tujuan Penelitian}

Untuk mengetahui perlindungan hukum dalam transaksi perdagangan berjangka komoditi ditinjau dari Fatwa DSN MUI Nomor 82 Tahun 2011 tentang Perdagangan Komoditi Berdasarkan Prinsip Syariah di Bursa Komoditi.

\section{Metode Penelitian}

Penelitian ini merupakan suatu penelitian yuridis normatif yang bersifat deskriptif analisis, karena penelitian ini berbasis pada analisis norma hukum. Oleh karena penelitian ini merupakan penelitian yuridis normatif, maka sumber datanya adalah berupa data sekunder berupa bahanbahan hukum, yang dilakukan melalui studi dokumen terhadap data sekunder yang diperoleh dengan menggunakan metode penelitian kepustakaan. Keseluruhan data sekunder yang diperoleh diolah dan dianalisis dengan menggunakan pendekatan kualitatif dengan menganalisis ketentuan-ketentuan hukum islam berdasarkan Fatwa DSN MUI Nomor 82 Tahun 2011 tentang Perdagangan Komoditi Berdasarkan Prinsip Syariah di Bursa Komoditi mengenai perlindungan hukum dalam perdagangan berjangka komoditi.

B. HASIL DAN PEMBAHASAN

Perdagangan Berjangka Komoditi Ditinjau Berdasarkan Fatwa DSN MUI Nomor 82 Tahun 2011 tentang Perdagangan Komoditi Berdasarkan Prinsip Syariah di Bursa Komoditi.

Perlindungan hukum yaitu kegiatan untuk melindungi individu dengan menyerasikan hubungan nilai-nilai atau kaidah-kaidah yang menjelma dalam sikap dan tindakan dalam menciptakan adanya ketertiban dalam pergaulan hidup antar 
sesama manusia. Perlindungan hukum merupakan suatu hal yang melindungi subyek-subyek hukum melalui peraturan perundang-undangan yang berlaku dan dipaksakan pelaksanaannya dengan suatu sanksi. Perlindungan hukum dapat dibedakan menjadi dua, yaitu : (Muchsin, $2003: 14)$

\section{a. Perlindungan Hukum Preventif}

Perlindungan yang diberikan oleh pemerintah dengan tujuan untuk mencegah sebelum terjadinya pelanggaran. Hal ini terdapat dalam peraturan perundang-undangan dengan maksud untuk mencegah suatu pelanggaran serta memberikan ramburambu atau batasan-batasan dalam melakukan suatu kewajiban.

b. Perlindungan Hukum Represif

Perlindungan hukum represif merupakan perlindungan akhir berupa sanksi seperti denda, penjara, dan hukuman tambahan yang diberikan apabila sudah terjadi sengketa atau telah dilakukan suatu pelanggaran.

Perlindungan bagi investor merupakan wujud dari kepastian hukum dalam transaksi perdagangan berjangka komoditi. Kepastian hukum adalah "Sicherkeit Des Rechts Selbst" atau kepastian tentang hukum itu sendiri. Hukum berfungsi sebagai perlindungan kepentingan manusia, penegakkan hukum harus memperhatikan 4 (empat) unsur yaitu kepastian hukum (Rechtssicherkeit), kemanfaatan hukum (Zeweckmassigkeit), keadilan hukum (Gerechtigkeit) dan jaminan hukum (Doelmatigkeit). Hukum berfungsi sebagai perlindungan kepentingan manusia, agar kepentingan manusia terlindungi, hukum harus dilaksanakan secara damai dan tertib (Muchsin, 2003 : 31).

Kepastian hukum merupakan ciri yang tidak dapat dipisahkan dari hukum, terutama untuk norma aturan hukum tertulis. Hukum tanpa nilai kepastian akan kehilangan makna karena tidak lagi dapat dijadikan pedoman perilaku bagi semua orang. Dimana tiada kepastian hukum, di situ tidak ada hukum atau yang dikenal dengan istilah ubi jus incertum, ibi jus nullum (H. Salim H.S., 2010 : 82).

Kepastian hukum menutut pandangan legalistik, sifatnya hanya sekedar membuat produk perundangundangan. Menurut penganut legalistik, janji hukum yang tertuang dalam rumusan aturan merupakan kepastian yang harus diwujudkan. Kritik terhadap penganut aliran legalistik adalah mereka melupakan bahwa janji hukum bukan sesuatu yang harus tetapi hanya sesuatu yang seharusnya dan apa yang seharusnya (das 
sollen) belum tentu terwujud dalam kenyataan atau realitas (das sein) (Achmad Ali, 2002 : 123).

Dalam Hukum Islam bahwa kegiatan ekonomi termasuk dalam perbuatan muamalah. Fiqh Muamalah merupakan aturan-aturan hukum Allah SWT dalam hal mengatur manusia dalam hal urusan sosial kemasyarakatan. Mayoritas ulama fiqih sepakat apabila adanya pengambilan kemanfaatan diperbolehkan selama kemanfataan tersebut tidak menyebabkan kerusakan atau merugikan salah satu pihak (Racmhat Syafei, 2000 : 8). Dalam perdagangan berjangka komoditi, transaksi ini harus dilaksanakan dengan syariat yang telah dijalankan dalam islam karena perdagangan berjangka komoditi memiliki peran penting dalam perekonomian (Zainudin Ali, 2008 : 34).

Majelis Ulama Indonesia telah mengeluarkan Fatwa DSN MUI Nomor 82 Tahun 2011 tentang Perdagangan Komoditi Berdasarkan Prinsip Syariah di Bursa Komoditi untuk mengatur transaksi perdagangan komoditi ini sesuai dengan syariat islam. Perdagangan berjangka komoditi berdasarkan Fatwa DSN MUI Nomor 82 Tahun 2011 tentang Perdagangan Komoditi Berdasarkan Prinsip Syariah di Bursa Komoditi adalah segala sesuatu yang berkaitan dengan jual beli komoditi kecuali forex dan valuta asing yang sistem perdagangannya diakhiri dengan penerimaan komoditi secara fisik sesuai waktu penyerahan yang telah disepakati dan dilakukan di bursa komoditi sesuai ketentuan fatwa yang berlaku. Konsep jual beli komoditi yang diatur dalam fatwa tersebut dalam ketentuan hukum perdata dikenal dengan istilah juridisch levering (Ridwan Syahrani, 2004 : 132).

Fatwa tersebut merupakan suatu bentuk pemberian perlindungan hukum dan kepastian hukum bagi masyarakat khususnya umat muslim sebagai acuan yang digunakan dalam melakukan transaksi perdagangan berjangka agar sesuai dengan nilai-nilai dalam islam. Dalam pembentukan akad pada saat awal perjanjian dalam transaksi perdagangan berjangka komoditi dalam hukum islam dilakukan dengan menggunakan akad murabahah dan akad wakalah dalam islam.

Murabahah adalah akad penjualan suatu barang (komoditi) dengan menegaskan harga belinya kepada pembeli dan pembeli membayarkannya dengan harga yang lebih tinggi yang dijadikan sebagai laba (keuntungan). Wakalah adalah seseorang yang mewakilkan nasabah untuk melakukan transaksi 
tersebut. Pada saat membuat akad/janji antar pihak dilarang untuk memiliki niat merugikan salah satu pihak.

Berdasarkan Fatwa DSN MUI Nomor 82 Tahun 2011 tentang Perdagangan Komoditi Berdasarkan Prinsip Syariah di Bursa Komoditi, ketentuan yang tidak boleh dilanggar pada saat melaksanakan transaksi perdagangan berjangka komoditi, diantaranya yaitu :

1. Bahwa dalam transaksi perdagangan berjangka komoditi tidak boleh mengandung unsur riba. Sebagaimana yang di sebutkan dalam QS AlBaqarah (2) : 275,

"Dan Allah telah menghalalkan jual beli dan mengharamkan riba"

2. Bahwa dalam transaksi perdagangan berjangka komoditi tidak boleh mengandung unsur gharar (ketidakjelasan). Sebagaimana yang disebutkan dalam Hadist Abu Hurairah

"Rasulullah SAW melarang jual beli hashah dan jual beli yang mengandung unsur gharar"

3. Bahwa dalam transaksi perdagangan berjangka komoditi tidak boleh mengandung unsur bathil. Sebagaimana yang di sebutkan dalam QS. Al-Nisa (4) : 29;
"Hai orang beriman! Janganlah kalian memohon (mengambil) harta orang lain secara batil,kecuali jika berupa perdagangan yang dilandassi atas sukarela di antara kalian."

4. Bahwa dalam transaksi perdagangan berjangka komoditi tidak boleh mengandung unsur najsy (penawaran palsu) sebagaimana yang disebutkan dalam Hadist Imam Bukhari.

5. Bahwa dalam transaksi perdagangan berjangka komoditi, kaum muslimin dilarang untuk mengharamkan yang halal atau menghalalkan yang haram.

Sebagaimana disebutkan diatas bahwa perdagangan berjangka komoditi dalam islam dilarang mengandung unsur ketidakjelasan (gharar). Unsur ketidakjelasan (gharar) menurut ahli figh, adalah sifat dalam muamalah yang menyebabkan sebagian rukunnya tidak pasti (mastur al-aqibah). Secara umum, gharar bisa diartikan kedua belah pihak dalam transaksi tidak memiliki kepastian atau kejelasan terhadap barang yang menjadi objek transaksi baik terkait kualitas, kuantitas, harga dan waktu penyerahan barang sehingga pihak kedua dirugikan (Oni Sahroni, 2016 : 77). 
Gharar ini terjadi bila mengubah sesuatu yang pasti menjadi tidak pasti. Contoh praktik gharar diantaranya adalah sebagai berikut (Adiwarman Karim, 2008 : 38):

a. Gharar dalam kualitas, seperti penjual yang menjual sapi yang masih dalam kandungan.

b. Gharar dalam kuantitas, seperti dalam kasus ijon.

c. Gharar dalam harga, seperti murabahah rumah satu tahun dengan margin 20 (dua puluh) persen atau murabahah rumah 2 (dua) tahun dengan margin 40 (empat puluh) persen.

d. Gharar dalam waktu penyerahan, seperti menjual barang yang hilang.

Gharar hukumnya dilarang dalam syariat islam, oleh karena itu melakukan transaksi atau memberikan syarat dalam akad yang ada unsur gharar nya itu hukumnya tidak boleh sebagaimana hadist Rasullullah SAW yang melarang jual beli yang mengandung gharar. Oleh karena itu, unsur gharar yang merugikan salah satu pihak dalam suatu transaksi dapat menimbulkan perselisihan dan permusuhan (Adiwarman Karim, 2008 : 32).

Islam adalah agama sempurna karena memberikan warna dalam setiap dimensi kehidupan umatnya, dan tidak terkecuali dunia ekonomi. Ekonomi islam berusaha mengendalikan nilai-nilai ekonomi dengan nilai aqidah dan etika. Kegiatan ekonomi yang dilakukan tidak hanya berbasis nilai materil melainkan terdapat sandaran transcendental di jalan Allah SWT sesuai dengan yang di atur dalam Al-Qur'an. Dalam hukum ekonomi syariah, bahwa kegiatan ekonomi merupakan kegiatan yang muamalah. Fiqh muamalah adalah aturan hukum Allah SWT yang ditunjukan untuk mengatur kehidupan manusia dalam urusan sosial kemasyarakatan. Mayoritas ulama fiqh sepakat bila ada pengambilan manfaat maka diperbolehkan. Tetapi mereka mensyaratkan tindakan mengambil manfaat yang dilakukan tidak menyebabkan kerugian, kerusakan salah satu pihak (Abdurauf, 1970 : 2-3).

Dalam transaksi perdagangan berjangka komoditi, proses jual beli komoditi dari pembeli ke pedagang harus melalui pialang berjangka menggunakan sistem komputerisasi atau handphone yang terhubung dengan bursa secara online, yang mengakibatkan barang yang diperjualbelikan tidak nyata atau berwujud pada saat transaksi berlangsung (Burharuddin S., 2009 : 53). Selain itu dalam transkasi perdagangan berjangka 
komoditi mengenal kontrak berjangka dan kontrak derivatif. Kontrak berjangka yang berkaitan mengenai kesepakatan antara investor dengan pihak pialang dalam hal memberikan keuntungan dikemudian hari.

Transaksi atau kontrak derivatif merupakan produk dari structured product. Adapun yang dimaksud dengan structured product yaitu produk yang dikeluarkan oleh bank yang merupakan kombinasi suatu aset (kekayaan) dengan derivatif dari mata uang valuta asing terhadap rupiah dengan tujuan mendapatkan (pendapatan) yang dapat mendorong transaksi pembelian valuta asing terhadap rupiah untuk tujuan spekulatif dan dapat menimbulkan ketidakstabilan nilai rupiah (Imam Buchori, 2009 : 152).

Dalam prespektif hukum ekonomi syariah, disatu sisi kontrak dan jenis transaksi pada barang yang bersifat fisik dan tunai, hal ini bisa ditolelir. Namun dalam transaksi perdagangan berjangka komoditi dengan adanya penyerahan barang atau keuntungan dikemudian hari, menimbulkan perbedaan karena adanya fluktuasi harga atas komoditas yang diperdagangkan. Transaksi derivatif yang motivasi spekulasi hukumnya adalah haram. Sedangkan jika dilakukan dengan tujuan untuk melindungi nilai rupiah di pasar, maka hukumnya mubah dan itu mengandung maslahah bagi kedua belah pihak. Karena pada dasarnya, Islam tidak melarang seseorang melakukan kesepakatan atau perjanjian dengan siapapun dan dalam bentuk apapun, asalkan mempunyai tujuan yang baik, bersih (terhindar dari riba, maysir, gharar) dan sanggup memenuhi syarat dan rukunnya (Imam Buchori, 2009 : 153). Berkaitan hal tersebut, transaksi perdagangan berjangka komoditi yang terkandung adanya unsur ketidakjelasan (gharar) yang tidak diperbolehkan dalam transaksi dalam hukum ekonomi syariah karena melanggar prinsip syariah (Burhanudin S., 2009 : 54).

Perdagangan Komoditi di bursa, baik yang berbentuk Perdagangan Serah Terima Fisik maupun yang berbentuk Perdagangan Lanjutan, hukumnya diperbolehkan dengan memenuhi syaratsyarat yang diatur dalam Fatwa DSN MUI Nomor 82 Tahun 2011 tentang Perdagangan Komoditi Berdasarkan Prinsip Syariah di Bursa Komoditi, diantaranya yaitu :

a. Komoditi yang diperdagangkan harus halal dan tidak dilarang oleh peraturan perundang-undangan,

b. Jenis, kualitas, dan kuantitas komoditi yang diperdagangkan harus jelas, 
c. Komoditi yang diperdagangkan harus sudah ada (wujud) dan dapat diserah terimakan secara fisik,

d. Komoditi yang diperdagangkan harus jelas dan disepakati pada saat akad (Ijab qabul),

e. Akad dilakukan melalui penawaran dan penerimaan yang disepakati para pihak yang melakukan perdagangan dengan cara-cara yang lazim berlaku di Bursa,

f. Penjual harus memiliki komoditi atau menjadi wakil pihak lain yang memiliki komoditi,

g. Penjual wajib menyerahkan komoditi yang dijual kepada pembeli dengan tata cara dan waktu dikemudian hari sesuai dengan kesepakatan,

h. Pembeli wajib membayar komoditi yang dibeli kepada penjual dengan tata cara dan waktu berdasarkan kesepakatan, dan

i. Pembeli boleh menjual komoditi tersebut kepada selain penjual sebelumnya atau pertama hanya setelah terjadi qabdh haqiqi atau qabdh hukmi atas komoditi yang dibeli.

Kemudian, mengenai barang komoditi yang ditransaksikan berdasarkan ketentuan Fatwa DSN MUI Nomor 82 Tahun 2011 tentang Perdagangan Komoditi Berdasarkan Prinsip Syariah di
Bursa Komoditi adalah seperti kopi, gula, kacang merah, dan jagung. Barang komoditi tersebut akan diserahkan setelah terjadinya kesepakatan jual beli yang dilakukan di bursa komoditi. Harga komoditi tersebut yang ditransaksikan, namun penyerahannya dengan fisik barang di waktu penyerahan yang telah disepakati oleh para pihak.

Selanjutnya, ketentuan bursa berjangka komiditi yang diatur dalam Fatwa DSN MUI Nomor 82 Tahun 2011 tentang Perdagangan Komoditi Berdasarkan Prinsip Syariah di Bursa Komoditi, diantaranya yaitu :

a. Bursa wajib membuat peraturan mengenai mekanisme perdagangan komoditi yang tidak bertentangan dengan prinsip-prinsip syariah,

b. Bursa wajib menyediakan sistem perdagangan di Bursa,

c. Bursa wajib melakukan pengawasan terhadap perdagangan di Bursa, dan

d. Bursa boleh menetapkan syarat-syarat tentang pihak-pihak yang melakukan perdagangan di Bursa.

Adapun mekanisme perdagangan berjangka komoditi yang diatur dalam Fatwa DSN MUI Nomor 82 Tahun 2011 tentang Perdagangan Komoditi Berdasarkan Prinsip Syariah di Bursa Komoditi, diantaranya yaitu : 
a. Penjual maupun pembeli komoditi di Bursa boleh menggunakan jasa agen/wakil pialang dengan akad wakalah.

b. Dalam hal kedudukan agen/wakil pialang penjual tidak boleh menjanjikan keuntungan kepada penjual atau pihak siapapun.

c. Dalam hal kedudukan agen/wakil pialang penjual dan pembeli, patuh pada ketentuan perdagangan dan terikat mengenai hak dan kewajiban.

d. Dalam hal kedudukan agen/wakil pialang pembeli sebagai wakil pembeli, tidak boleh menjanjikan harga yang pasti kepada pembeli.

Kemudian dalam hal terjadi perselisihan di antara para pihak dalam perdagangan berjangka komoditi, maka penyelesaiannya berdasarkan Fatwa DSN MUI Nomor 82 Tahun 2011 tentang Perdagangan Komoditi Berdasarkan Prinsip Syariah Di Bursa Komoditi yaitu dilakukan berdasarkan musyawarah untuk mufakat. Dalam hal tidak tercapai kemufakatan, maka penyelesaian perselisihan dapat dilakukan melalui Badan Arbitrase Syariah atau berdasarkan peraturan perundang-undangan dan sesuai prinsip-prinsip syariah.

\section{PENUTUP}

Perlindungan hukum dalam perdagangan berjangka komoditi bagi investor muslim diatur dalam Fatwa DSN MUI Nomor 82 Tahun 2011 tentang Perdagangan Komoditi Berdasarkan Prinsip Syariah di Bursa Komoditi yang merupakan suatu bentuk pemberian perlindungan dan kepastian hukum bagi masyarakat atau investor muslim dalam melakukan transaksi perdagangan berjangka komoditi yang memiliki pengertian, mekanisme, struktur organisasi, pengawasan dan penyelesaian sengketa tersendiri dan mengandung prinsip syariah.

Dalam fatwa tersebut diatur bahwa suatu perdagangan berjangka komoditi syariah merupakan suatu jual beli komoditi terkecuali bentuk forex dan valuta asing yang mana pada pelaksanaan transaksi harus diakhiri dengan adanya penyerahan barang komoditi yang diperjual belikan. Agar terhindar dari unsur ketidakjelasan (gharar) yang dilarang dalam suatu perdagangan berjangka komoditi.

Transaksi perdagangan berjangka komoditi berdasarkan fatwa bertujuan sebagai sarana melindungi nilai rupiah di pasar. Karena pada dasarnya, Islam tidak melarang seseorang melakukan kesepakatan atau perjanjian dengan siapapun dan dalam bentuk apapun, 
asalkan mempunyai tujuan yang baik, bersih (terhindar dari riba, maysir, gharar) dan sanggup memenuhi syarat dan rukunnya. Sedangkan apabila dilakukan atas motivasi spekulasi hukumnya adalah haram.

\section{DAFTAR PUSTAKA}

Abdurauf, Al-Qur'an dan Ilmu Hukum, Bulan Bintang, Jakarta, 1970.

Achmad Ali, Menguak Tabir Hukum, PT. Toko Gunung Agung, Jakarta, 2002.

Adiwarman Karim, Bank Syariah Analisis Fiqh Keuangan, PT. Raja Grafindo Persada, Jakarta, 2008.

Allysthia M. Renti D., Perdagangan Berjangka Komoditi dan Kajian Hukum Kontrak Derivatif Forex dan Indeks Saham Asing dalam Industri Perdagangan Berjangka di Indonesia, Jurnal Hukum dan Pembangunan, No.1 Vol. 1 , Januari 2012.

Andam Dewi, Hermanto Siregar, Sri Hartoyo, Analisis Kontrak Berjangka Olien di Bursa Berjangka Jakarta, Jurnal Management dan Agribisnis, No.1 Vol. 8, PT. Bursa Berjangka, Jakarta, Maret 2011.
Burharuddin S., Hukum Kontrak Syariah, Sinar Grafika, Yogyakarta, 2009.

Fatwa DSN MUI Nomor 82 Tahun 2011 tentang Perdagangan Komoditi Berdasarkan Prinsip Syariah di Bursa Komoditi.

Galih Mahendratama Putra, Budiharto, Siti Mahmudah, Pelaksanaan Perjanjian Kerjasama Investasi Antara Investor Dengan Perusahaan Pialang Berjangka, Diponegoro Law Review, Volume 1, Nomor 4, Tahun 2012.

H. Salim H.S., Perkembangan Teori Dalam Ilmu Hukum, PT. Raja Grafindo Persada, Jakarta, 2010.

Imam Buchori, Transaksi Derivatif Dalam Perspektif Hukum Islam, Al-Qānūn, Vol. 12, No. 2, Desember 2009.

Kitab Undang-Undang Hukum Perdata (Burgerlijk Wetbook).

Muchsin, Perlindungan dan Kepastian Hukum Bagi Investor di Indonesia, Magister Ilmu Hukum Pascasarjana Sebelas Maret, Surakarta, 2003.

Oni Sahroni, Riba Gharar dan KaidahKaidah Ekonomi Syariah, PT. Raja Grafindo Persada, Jakarta, 2016. 
Citra Julian Lestari, Perlindungan Hukum Dalam Pergadangan Berjangka Komoditi Berdasarkan....

Rachmat Syafei, Fiqh Muamallah, Pustaka

Setia, Bandung, 2000.

Ridwan Syahrani, Seluk Beluk dan Asas-

Asas Hukum Perdata, Alumni,

Bandung, 2004.

Undang-Undang Nomor 10 Tahun 2011

tentang Perdagangan Berjangka

Komoditi.

Zainudin Ali,Hukum Ekonomi Syariah, Sinar Grafika,Jakarta, 2008. 